\title{
PRINCIPLE OF EQUALITY AS THE BASIS OF THE CONSTITUTIONAL ORDER
}

DOI: $10.47743 /$ rdc-2017-2-0005

Dr.sc. Dubravko LJUBIĆ

\section{Abstract}

One of the fundamental principle of the constitutional order is "constitutional equality". This principle represent the emergence of civil societies founded on maximum freedom equality and brotherhood and makes its appearance in the society through the maxim and in the same situation which should be treated equally and similarly. The content of this principle is also the foundation of freedom and social justice in every democratic society.

Keywords: Constitution; minorities; electoral rights; fundamental rights and freedoms

\section{Introductory remarks}

The legal order realistically represents the limitation of absolute freedom by defining and limiting the rules of conduct of the addressees with regard to the existence of the public interest and the survival of the necessary interaction of the subjects when entering into social relations or participation in the distribution of economic and cultural goods. There is no legal order that gives happiness to every individual if the definition of happiness is approached subjectively, because the perception of happiness of an individual does not, in principle, coincide with the scope and content of the conception that others associate with this term. The legal system can not be fair even when trying to achieve the highest possible level of happiness in the widest possible circle of addressees. The happiness that a legal order can provide is happiness in the collective sense of the concept, that is, the legal order can ensure for the individuals the satisfaction of their needs in the method and the scope of a particular right ${ }^{2}$. On the other hand, the Constitution has to guarantee the individual or social groups protection from certain decisions that most citizens might want to bring, even in situations where this majority works in accordance with their perception of the realization of the

\footnotetext{
$1 \mathrm{PhD}$ in Constitutional law, Faculty of Law, University of Zagreb, Croatia. The Constitutional Court of the Republic of Croatia, Senior legal adviser - menthor Head of the Preliminary investigation procedure department.

2 See H. Kelsen, Opća terija prava i države (General Theory of Law and the State), in Archives for Legal and Social Sciences, Belgrade, 1951, pp. 18-21.
} 


\section{Dubravko LJUBIĆ}

common good or common interest. Some constitutional provisions are designed in a way that undoubtedly and directly ensures the realization of certain rights to addresses by prescribing their minimum content. Other provisions are regulated as less specific standards whose content comes from interpreting those who have to apply them in specific cases or in example situations. These standards are given through the linguistic expression of ethical principles that are subject to redefinition according to civilizational achievements of society ${ }^{3}$.

One of the fundamental terms of the constitutional order is "constitutional equality". The very idea of equality of action is the emergence of civil societies founded on maximum freedom, equality and brotherhood. Although seemingly related to the descriptive content of the notion of human dignity, equality still governs the other dimension of the relationship between authority and the individual. While human dignity is a minimal content that makes the essence of the concept of a man free from the influence of each and every state government, equality regulates the way in which a legal order must treat an individual as a member of a society or a social group without imposing special and disproportionate burdens for whose existence there is no logical base in the fundamental postulates of society. While human dignity is the source of the defensive constitutional rights that rule erga omnes, equality as a constitutional principle is a means through which the consequences of the plurality of social and legal relations in which various entities within a particular social community enter are perceived as just. It is noteworthy that there are no two people in the world that are identical in most physical properties or most socially-conditioned traits that society holds relevant. It is therefore justifiable to ask the question of how social life marked by differences can implement the principle of constitutional law based on egalitarianism.

\section{Theoretical definition}

Determining the term "equality" can have a purely philosophical approach that expresses attitudes about what the content of this term should actually be in relation to the definitions contained in the core norms of a society. On the other hand, the approach can be descriptive, describing the occurrences in a social group caused by the action of a legal order, whereby the content of the legal consequences on the fundamental sphere of the individual can draw certain regularities that are sufficient to set operational definitions. Determining the content of the constitutional principle of equality can also be obtained from comparing the legal position of individuals, minority and majority social groups caused by certain normative regulation. But in order to truly establish the principle of the construction and survival of the society of equals, it is necessary to synthesize all the results obtained by the above-mentioned particular

${ }^{3}$ See R. Dworkin, Taking Rights Seriously, Kruzak, Zagreb, 2003, p. 149.

CONSTITUTIONAL LAW REVIEW 


\section{Principle of equality as the basis of the constitutional order}

methods. Evidence of equality in society is checked through a comparison of actions of the legal system towards the addressees. The scope of the principle of equality is not in its abstract definition, but in its constitutional foundation as a concrete fundamental principle of organization of society. The principle of equality can not act absolutely in all segments of social relations, but in any case it must be a defense against discrimination in the sphere of fundamental rights and freedoms immanent to every individual. Objectively, equality is the principle that all people are in their position equal to the authorities and the legal system of a community, or the principle according to which legal regulations, legal protection and legal punishment are equally valid for all independently of the personal characteristics of individuals such as their origin, social status or economic power. In a subjective sense, equality is the legitimate expectation of every individual that positive law will act and be applied to everyone equally.

The principle of equality can only be achieved in societies where people's position does not depend on their genetic conditionality. Social conditionality may appear as a source of difference in the ability to acquire rights among individuals, but not in the domain of fundamental rights. People are not born equal, but by birth they become equal members of a society who by its own consciousness and social worldview is willing to guarantee to everyone equal scope of rights. Democratic society must establish the living conditions that allow everybody to exist in relation to equality with others, but equality can not be enforced by any authority. In democracies, members of society, due to the principle of equality, can not be marginalized on any socially relevant basis, nor may the quality of their life depend on anyone's will or mercy. Equals can not be the object of domination, nor can they be exploited, alienated from social means, culture of their society, or from the possibility of participating in social life 4 . The only thing that a democratic society can guarantee is an equitable distribution of rights, freedoms and limited resources based on a constitutional principle that assumes equal participation of all members of the society in distribution until there is evidence of a relevant socially recognized circumstance justifying different treatment.

The principle of equality can not be identified with the content of the constitutional law of human dignity or personality. Equality is focused on the relationship between social centers of power and other social entities in the organization of social relations, while the latter two are the origin of constitutional rights and freedoms protected by the basic norm. In this respect, constitutional rights derive from human dignity as the basis of man's being, while constitutional freedoms emerge from human personality understood as the assumption of positioning each individual within a particular social community.

The principle of equality makes its appearance in the society through the maxim that the same should be treated equally and similarly. However, such an approach is

\footnotetext{
${ }^{4}$ See E.S. Anderson, What is the Point of Equality, (January 1999), Ethics, University of Chicago, 109 (2), pp. 287-337.
} 


\section{Dubravko LJUBIĆ}

superficial and insufficient in the constitutional law sense. Every classification of individuals or social groups that are equal to a certain criterion inevitably on the other side causes the existence of social entities that are necessarily unequal according to their features that do not have any impact on the goal and the essence of performed classification. At the same time the intensity of possessing the targeted characteristics according to the purpose of the classification is not equal even within the group. Therefore, in the case of equal treatment of the same, it is actually a realistic treatment of the different in the same way. Therefore, it is more purposeful to treat the presumed equality in which the requirement for treat equal equally is relativized through the possibility of different treatment in each case where there is a socially acceptable reason for differentiation. Through the basic principles, the principle of equality thus enters into a positive legal system, whereby the state and other power centers are obliged to prescribe and prove the existence of a legal basis in each case of encroachment of rights and obligations of the addressees, which in their base have their unequal treatment. In addition to the explanation of the legal basis of differentiation in each particular case, the basic rule generally prescribes general circumstances which can not be the basis for distinguishing the legal norms between the addressees in any case. The constitutional state establishes its legal order, starting from the finding that everyone is equal before the law. The law can introduce diversity into social order only in accordance with the constitutional taxation of the legal basis for differentiation, that is, the legislator is prohibited from making any distinction between the addressees on the basis of arbitrarily selected bases ${ }^{5}$.

Everything that is born and has the potential to be human should be equally treated by society. However, since people are really different, the constitutional principle of equality can only be achieved through an action in which the social order holds certain differences in granting of rights and imposition of obligations constitutionally irrelevant. Most constitutional orders operates on the principle that equal are treated equally. The real consequence of this approach is that any difference between the addressees can be taken as the basis for their differentiation, that is, as an important thing that justifies a different treatment of individual or smaller social groups. The principle of equality expressed through the egalitarianism of all before the law here would not be able to effectively perform its function because law enforcement bodies would only have to implement legal rules regardless of address characteristics, unless the subject matter explicitly requires differentiation. If the legal order recognizes certain rights only to certain social groups then the principle of equality before the law would be formally preserved in all those situations in which the authorities of the state decide that all others are deprived of said rights independent of the fact that such a decision would reflect fundamental rights and freedoms deprived. Social order should ensure

5 See S. Barić, S. Vincan, Ustavnopravno načelo jednakosti i pravno uređenje istospolnih zajednica, PF Split 1/2013, pp. 86-88. 


\section{Principle of equality as the basis of the constitutional order}

equal treatment to everyone whereby their personal characteristics should be taken into account to the extent that they do not represent treatment that can be considered discrimination for other members of the society ${ }^{6}$.

Everyone in the constitutional justice system based on the principle of equality must have at least two constitutionally protected legitimate rights. First and foremost, it is the right to be treated as equal, which is practically the right to treat each addressee of the legal order with equal care and respect. This right is fundamental in every democratic society because it prevents discrimination on a socially relevant basis. On the other hand, every person has the right to equal treatment, that is, the right to allotment of some opportunities, resources or burden. The right to equal treatment derives from the right to be treated as equal. The social community as a whole always has the obligation of impartial behavior towards its members, which the authorities of the state government, as well as all other centers of social power, are obliged to perform as their responsibility. The obligation to protect every member of society is primarily on groups and organized centers of authority, but it does not relieve the duty of acting on the same pattern and all other individuals who, because of their economic or on other basis established social forces, have the potential to affect the existence of others. Equality-based society must respect its ethical responsibility for the allocation of social resources that gives each individual the choice of his or her purpose. Constitutional equality does not find its starting point in political power. Democratic society is the only form of government that is based on regard and respect for the individuality of each individual, giving them equal chances for their social activity ${ }^{7}$.

Thus, the principle of equality constitutes a constitutional guarantee of equitable inclusive treatment. All members of a democratic society have a demand for equal share in the distribution of basic social goods and freedoms, except in cases where unequal social treatment can be justified by generally accepted reasons. In doing so, the foundation of differentiation must as legitimate be recognized by the constitutional order and must serve the realization of benefits for people to whom certain legal regulation of social relations directly relates to, but in the long term also for everyone else who on the same legal basis participates less in the distribution. The principle of equality is the instrument of removing the socially imposed oppression of its members and the condition of exercising personal liberty and social justice. But this principle can not be absolute. Otherwise, egalitarianism could turn into a mere justification of bad luck, or a means of correcting the alleged cosmic injustice. The duty of the constitutional principle of equality is not to eliminate the personal negative consequences or personal misfortune from the life of the individual. The principle of equality is not an instrument by which everyone gets what they think objectively belongs to them, but is the principle

\footnotetext{
${ }^{6}$ See H. Kelsen, What is Justice, Pravni život 12/1995, pp. 18-23.

${ }^{7}$ See R. Dworkin, What is Equality?, in Philosophy and Public Affairs, 10 (1981), pp. 283-345, and Taking Right Seriously, Zagreb, 2003, pp. 294-299.
} 


\section{Dubravko LJUBIĆ}

of establishing a social community in which people are getting into social relations with their equals. Otherwise, the principle of equality and the evident inadequacy of social resources to meet all individual needs would turn into undesirable egalitarianism in social regression ${ }^{8}$.

\section{Principle of equality in the constitutional order}

\section{of the Republic of Germany}

The principle of equality finds its expression in German constitutional law in the provisions contained in Article 3 of the Basic Law (GG) ${ }^{9}$. The above-mentioned provisions of the GG are familiar with the general principle of equality enshrined in para. (1). The following two paragraphs cover the special principles of equality, which relate to para. (1) as a special rule to the general. According to the general principle, all people are equal before the law. If this provision were to be interpreted grammatically, then it would have to be assessed not as a norm, but as an anthropological statement. GG would then, in the dispute between genetic theories and theories of surroundings, took a stand in favor of the latter. However, in its practice, from the beginning the Federal Constitutional Court (BVerfG) has avoided such an interpretation that would derive from the linguistic interpretation of the basic norm. From its solutions, it is clear that there are no two men or two factual states that are equal to each other in every respect. When applying the principle of equality, it is therefore important to separate the relevant from irrelevant differences. According to constitutional jurisprudence, Article 3 para. (1) of the GG is the basic norm which requires state bodies equal treatment of inherently unequal or, at least, not exactly the same persons, that is, factual states. So here we are not talking about creating equality between the various regulations, but it is a situation in which the application of the law must be characterized by the principle of equal treatment ${ }^{10}$.

Concerning the material content of the general principle of equality, in practice BVerfG is in constant evolution. The first interpretation of the general principle of equality is consistently aligned with the ban on arbitrariness. According to the original interpretation of the BVerfG, the principle of equality has been violated when no reasonable, inherent or incidental cause can be found for legal differentiation or unequal treatment, or when the legal definition given must be characterized as arbitrary. Regardless of whether there is an unequal treatment of the same or the same treatment of different factual conditions. Here the decisive thing is the sole existence of

\footnotetext{
${ }^{8}$ A regressive equality - see D. Parfit, Equality and Priority, Ratio, volume X, Oxford, 1997, pp. 202-221.

${ }^{9}$ Article 3 of GG reads: (1) All people are equal before the law. (2) Men and women are equal. (3) No one shall be deprived of their rights, irrespective of their sex, origin, race, language, homeland and birth, religion, religious or political beliefs.

10 BVerfGE 26, 302.
} 


\section{Principle of equality as the basis of the constitutional order}

an objective reason or the absence of such a reason for a particular legal arrangement, where BVerfG has never assessed the content of arbitrariness in its subjective sense. BVerfG emphasized in its solutions that subjective arbitrariness does not lead to the determination of anti-constitutionality, but the objective, actual and unambiguous inadequacy of legal measures in relation to the actual situation that it wishes to regulate $^{11}$. This formulation lives in the BVerfG practice since October $23,1951^{12}$, and even today, although somewhat altered, exists as a permanent establishment of constitutional-law practice ${ }^{13}$.

Equating the principle of equality with the prohibition of arbitrariness demonstrated its inadequacy in the development of the BVerfG judiciary in connection with the free development of personality. In order to reconcile the gap that appeared between the interpretation of the concepts of freedom and equality, a new and constructed interpretation of the general principle of equality was introduced ${ }^{14}$. According to a new interpretation, the general principle of equality requires all people to be treated equally before the law. Consequently, equality is generally violated when a group to which the norm is referring to is treated differently compared to another group of addressees of the norm, although there are no differences between these two groups nor severity that could justify unequal treatment. The real difference between the new formulation and the previously described content of arbitrariness consists in grading the severity of the consequences that the violation of this principle produces for the addressee. While the present formulation has already allowed the existence of equal and unequal treatment by the state whenever an objective reason for this can be found, the new formula establishes the link between the degree of equal or unequal treatment and the objective reason justifying it. The reason for the unequal treatment must be of such a kind and such weight that it is able to justify the procedure of the state organs. Therefore, it would be concluded from BVerfG practice that the new formulation should be applied not in the comparison of individual persons or factual states, but when it comes to comparison of groups of persons. Thus, BVerfG uses a new formula precisely when it comes to issues of "equality of groups" that arise when laws that encompass a large circle of addressees are introduced into a legal system, such as those with a tax or social theme, although here the fact of the plurality of group members is not of crucial importance. The difference and the burden in the treatment that the legislator introduces through its normative activity among the social groups justifies the Court's activity with its severity and credibility. A new approach to the notion of equality requires validity in the overall field of application of this general principle, not just in some part of that domain. The existence of a new approach,

\footnotetext{
11 BVerfGE 10, 234; BVerfGE 9, 338.

12 BVerfGE 1, 14.

13 See Maunz-Düring, Grundgesetz, Kommentar, München, 1999 (commentary on the Article 3/1 GG), pp. 353-358.

141 BvL 50, 89/79; 1 BvR 240/79 (07/11/1980).
}

CONSTITUTIONAL JURISDICTIONS 


\section{Dubravko LJUBIĆ}

however, does not exclude the possibility of prohibiting arbitrariness in all those cases where this is considered opportune, that is, in situations where a link between the legal rule and the severity of the consequences can not be established.

In addition to the general principle of equality before the law, Article 3 of the GG also contains a provision on equality of men and women. This is a special protection set by the basic norm by which the state seeks to correct the historical state of difference in rights between men and women. But not in the domain of gender equality, but in the area of marriage and family life. In the German constitutional law system, the equality of men and women has risen to the rank of independent constitutional law. They do not have to be equal in the position they take in society as individuals on the basis of their personal qualities, but they must be equal in the realization of fundamental and all other subjective rights which they belong to without discrimination on any ground. In its practice BVerfG $^{15}$ points out that unequal treatment of men and women can not be justified by functional or biological differences. There are no significant differences between men and women that could be used as a legitimate cause for a different treatment in the normative activity of the legislator ${ }^{16}$. It would be wrong to conclude that the equality established by the basic norm relates solely to the protection of the position of women in society. BVerfG reacts in all situations in which equality of men and women is violated in view of their family situation. The provision of Article 3 para. (2) of the GG prohibits the difference in marital and family status to be taken as an important factor for the differentiation of rights ${ }^{17}$. However, this does not exclude the possibility of editing certain differences arising from the specific distinction between the necessary biological characteristics and the differences between men and women that objectively exist ${ }^{18}$.

Para. (3) of Article 3 of the GG imposes a ban on discrimination on grounds of sex, origin, race, language, homeland, birth, religion and religious and political beliefs. It equally defends the placement of a group of people in a constitutionally unacceptable privileged position towards other addressees, as well as the situation when a certain

${ }^{15}$ BVerfGE 10, 59; 15, 337 (343); 21, 329 (343); 31, 1 (4).

16 By elaborating these principles, BVerfG not only controlled the constitutionality of laws and their application, but was also the initiator of changing customs. For example, in its resolution of 31 May 1978 (BVerfGE 48, 327) it pointed out that "in the earlier judicial practice the prevalent attitude was that the unity of the family is expressed by the surname of a man, justified by the fact that the husband represents the family community towards the outside and that within the family community there are obligations and tasks that are not identical with the tasks of a woman. It is unacceptable that only a husband generally represents marriage towards the outside and even in cases where he is the only one who works and the woman is constrained to run the household. This is especially unacceptable in cases of marriage in which both partners work. The role of women in the process of work contributes to the withdrawal of the earlier generally accepted position that it is inconsistent with the natural distribution of tasks in marriage and family when a woman is working and does not limit herself to fulfilling her tasks in marriage and family".

17 BVerfGE 52, 369: "It is incompatible with Article 3 para. (2) of the Constitution that the right to a free working day for home work is recognized for unmarried women with their own household but not to men in the same situation".

${ }^{18}$ BVerfGE 3, 225 (242); 5, 9 (12); 10, 59 (74); 31, 1 (4); 43, 213 (225). 
group of people is unreasonably being placed in a disadvantaged position. When a legislator privileges a group of persons, then BVerfG can not re-establish equality by establishing a new text of the law that will include other persons who were not initially included instead of a legislator. The BVerfG decisions must preserve the legislator's freedom of standardization, especially given that, following the BVerfG decision, the legislator will have in particular a provision on the prohibition of privilege or discrimination. In the case of discrimination, as well as in the case of privilege, the BVerfG pronounces the legal basis as constitutionally null and void due to its contradiction with the Constitution. Thus, the provision of para. (3) of Article 3 of the GG stipulates that no one can be discriminated or privileged. This constitutional right is violated only when there is a deliberate intention to neglect or privilege for one of the reasons mentioned above. Inequalities that arise as a result of regulations that have a different intent or which arise by the very nature of the matter can not be subjugated to violations of this fundamental right ${ }^{19}$.

\section{Principle of equality in the constitutional order}

\section{of the Republic of Croatia}

Basis of its interpretation the Croatian Constitution determines in the content of Article 3, which establishes the highest values of the constitutional order ${ }^{20}$. The principle of equality in our Constitution takes on a prominent place, immediately behind the personal freedom and freedom of expression of personality. Such a determination suggests that any general and individual measure of public authority must be substantially aligned with the ban on differentiation of addressees according to socially irrelevant properties. Its particular expression comes from the principle of Article 14 of the Constitution ${ }^{21}$. In addition, with the entry of the Republic of Croatia into full membership of the European Union, the power of the Lisbon Treaty and the provisions of Article 134 of the Constitution ${ }^{22}$ and the reception into the domestic social order of the Charter of Human Rights of the European Union, the principle of equality gains within our constitutional order a special and much stronger position. In fact, the third

\footnotetext{
${ }^{19}$ BVerfGE 8, 28; 6, 273; 39, 334; 7, 155.

${ }^{20}$ Freedom, equality (...) are the highest values of the constitutional order of the Republic of Croatia and the basis for the interpretation of the Constitution.

21 (1) Everyone in the Republic of Croatia has rights and freedoms regardless of race, color, sex, language, religion, political or other opinion, national or social origin, property, birth, education, social status or other characteristics. (2) All are equal before the law.

${ }^{22}$ International treaties that have been concluded and ratified in accordance with the Constitution and published, and which are in force, form part of the domestic legal order of the Republic of Croatia and are legally enforceable above the law. Their provisions may be amended or terminated only under the terms and in the manner determined by them, or in accordance with the general rules of international law (Article 134 of the Constitution).
} 


\section{Dubravko LJUBIĆ}

part of the Charter of Fundamental Rights of the European Union is entitled "Equality". Although universal equality is a value that is embedded in all the documents and the EU judicature ${ }^{23}$, the Charter goes a step further than all the valid sources of European law. It generally protects any form of discrimination on any ground such as, for example, a wide list of personal distinctions ${ }^{24}$. Furthermore, the Charter in Article 21 para. (1) prohibits any discrimination on any ground such as sex, race, color, ethnic or social origin, genetic traits, language, religion or belief, political or other opinion, membership of a national minority, property, birth, disability, age or sexual orientation. Para. (2) of this Article shall in principle prohibit discrimination on grounds of nationality, except where expressly derived from international treaties. Apart from prescribing the general prohibition of discrimination, the Charter specifically elaborates two forms of equality. The first is the equality of all before the law ${ }^{25}$. The second is the equality of men and women ${ }^{26}$. The provisions of the Charter, which establish equality, undoubtedly result in the prohibition of discrimination of any kind. It is socially unacceptable to determine any action by the competent authorities of the state that has the effect of favoring a particular social group at the expense of others. However, with the general prohibition of discrimination, the Charter recognizes the possibility of establishing privileges which determine certain additional rights of certain social groups that do not go to the detriment of the rights of others, or the establishment of certain benefits to certain addressees under the law under precisely determined circumstances. Explicitly, the possibility of establishing privileges is contained in the provision of Article 23 para. (2) of the Charter. It establishes a rule according to which the principle of equality does not prevent the maintenance or taking of measures which provide special privileges to the

\footnotetext{
${ }^{23}$ The founding treaty of the European Community contains this principle in its original provisions. Article 2 and Article 3 of this Treaty establish equality between men and women, whereby Article 13 obliges the Community to promote equality and to take appropriate measures to remove all sources of discrimination based on sex, racial or ethnic origin, religion, disability, age of sexual orientation. From the aforementioned provisions, definition of descriptive but also the prescriptive equality is clear (see S. Barić, The Philosophical Concepts of Equality, Proceedings of PF Rijeka, No. 2/2000, pp. 841-849). Also, the Maastricht Treaty has contributed to the extension of the principle of equality and to other areas (Article 17-22 establishes equality on the basis of citizenship, Article 141 lays down the principle of equal pay for equal work regardless of age and sex).

In European judication, the principle equality has always been interpreted and widespread, as the sources of European law contained. Thus, in the seventies, equality has taken on board the general principle of the prohibition of discrimination [ECHR Frilli v. Belgium (22/06/1972), Sotigu v. The German post office (12/02/1974)].

24 The European Convention for the Protection of Human Rights and Fundamental Freedoms now provides for the enjoyment without discrimination of only the rights contained in that Convention. Such a situation is being changed for countries that have ratified Article 1 of Protocol 12 to the European Convention, which contains a general prohibition of discrimination, and it is to be expected that the prohibition of discrimination will be treated as a value that enjoys court protection alone.

${ }^{25}$ Article 20 of the Charter reads as follows: "All are equal before the law". This provision points to the rule of law as one of the basic features of a democratic society. Laws apply to all addressees equally, irrespective of the fact that they belong to the Union.

${ }^{26}$ Article 23 para. (1) of the Charter reads as follows: "Men and women are equal in all areas, including employment, work, and wages".
}

CONSTITUTIONAL LAW REVIEW 
subordinated sex. Implicitly, the possibility of constitutional privileges arises from the dictation and content of the provisions contained in the third part of the Charter, which establishes the rights of special social groups such as children, elderly persons and persons with disabilities, i.e. recognizing respect for religious, cultural and linguistic diversity ${ }^{27}$.

The previous practice of the Constitutional Court of the Republic of Croatia in relation to the content of Article 14 of the Constitution as a legal basis for establishing a constitutional complaint was not consistent. Looking at the practice of the Constitutional Court regarding decision-making or resolution in proceedings instituted by constitutional complaints based on allegations of breach of the principle of equality, the following forms of action are apparent. Initially, the content of Article 14 of the Court was observed synthetically through the prism of the general principle of equality without entering specifically into the separate content of an item. The right to non-discrimination was observed through communion with the principle of equality before all law and equality in the procedural position of the parties contained in Article 26 of the Constitution ${ }^{28}$. Subsequently, the provisions of Article 14 were observed as a single expression of the principle of equality ${ }^{29}$, while the provisions of Article 26 of the Constitution were considered as a legal basis for a constitutional complaint only in cases where the allegation of alleged violation of constitutional law was related to a proceeding conducted before the competent authorities of the judiciary which was attended by domestic and foreign natural or legal persons ${ }^{30}$. Following the synthetic observation of the right to non-discrimination, the practice of the Constitutional Court has begun to independently treat this provision as the legal basis for a constitutional complaint $^{31}$. Subsequently, the Court took the view that this is not a matter of statutory constitutional law ${ }^{32}$, although such an attitude is not always repeated consistently ${ }^{33}$. To conclude, in the new practice the Court has the possibility of submitting a constitutional complaint indicating the existence of discrimination in connection with the prior and further exhaustion of a special legal route ${ }^{34}$. Thus, para. (1) of Article 14 became an

\footnotetext{
${ }^{27}$ Article 22 of the Charter reads as follows: "The Union respects cultural, religious and linguistic diversity". Article 24 of the Charter reads as follows: "(1) Children are entitled to the protection and care that is necessary for their well-being. They have the right to freely express their views. Such attitudes will be taken into account in issues that concern them, according to their age and maturity. (2) The best interests of the child are primarily taken into account in all child-related proceedings, whether undertaken by a state authority or a private institution. (3) Every child has the right to regularly maintain personal contacts and direct contact with both of their parents, unless it is against the child's interest". Article 25 of the Charter reads as follows: "The Union recognizes and respects the rights of older people to a dignified and independent life and to participate in social and cultural life". Article 26 of the Charter reads as follows: "The Union recognizes and respects the rights of persons with disabilities to benefit from measures that ensure their independence, social and labor integration and participation in community life".

${ }^{28}$ U-III-272/1999 (12.03.2002.); U-III-749/1998 (22/03/2001).

${ }^{29}$ U-III-2914/2002 (16/05/2007); U-III-85/1996. (28/02/2001).

30 U-III-765/2008 (31/03/2009); U-III-884/2004 (16/11/2004).

${ }^{31}$ U-III-2478/2004 (21/11/2006).

32 U-III-2460/2006 (31/03/2009); U-III-1101/2007 (31/03/2009); U-III-33/2008 (31/03/2009).

33 U-III-358/2009 (09/06/2010).

34 U-III-1097/2009 (09/11/2010).
}

CONSTITUTIONAL JURISDICTIONS 


\section{Dubravko LJUBIĆ}

independent legal basis for filing a constitutional complaint, but only in the case of exhaustion of a special legal remedies.

On the other hand, the principle of equality of all before the law had a significant role in the constitutional control of individual governmental measures. Primarily because of the fact that today's constitutional lawsuit is not related to the institute of constitutional complaint, it has not been possible for the authorities to discern decision-making on violations of constitutional law from institutional trials on lawfulness. The initial practice of constitutional courting has given us the practice of constitutional lawsuits that was in principle very similar to those practiced by regular courts in the exercise of their jurisdiction. Thus, in the plenum, they decided on any constitutional complaint that passed the formal admissibility test, irrespective of the fact of the apparent lack of constitutional legal substrate. Apart from the equality of all before the law being the fundamental legal basis for challenging the constitutional complaint, it was most often the primary and most important one in assessing the existence of a violation of the applicant's constitutional rights ${ }^{35}$. In the recent practice of the Court, there is a noticeable shift from the interpretation of Article 14 para. (2) of the Constitution as the legal basis for submitting a constitutional complaint ${ }^{36}$. The trend is a deviation from the judicial practice manifested through the assumption of the guardianship of the legality of the legal system in general, towards the role of the guardian of constitutionality and supremacy of the Constitution. The focus is on constitutional issues when deciding on constitutional complaints, while violations of the law are treated only in case of their impact on the existence of a violation of constitutional law. However, due to the inconsistency in the proceedings, there was no real progress in the Croatian constitutional court. Mostly because of the copying of the practice of the European Court of Human Rights which, in view of its incidental nature, is deprived of the principle of consistency. At the same time, by emphasizing the procedural issues in its decision-making, the Constitutional Court has overturned the control of the legality of the individual acts by the sole control of the form of the proceedings ${ }^{37}$.

As far as the abstract control of constitutionality is concerned, our Constitutional Court has in its recent practice declaratively accepted the standards of equality that correspond to those existing in the constitutional states ${ }^{38}$. However, when applying the framework standards of equality principle to a general rule of normative power, the Court did not establish and express benchmarks to consistently isolate the criteria for determining the content of this principle in the constitutional order of the Republic of Croatia.

\footnotetext{
${ }^{35}$ U-III-1975/2009 (13/01/2010); U-III-1350/2007 (07/10/2009); U-III-833/2004 (06/07/2006).

${ }^{36}$ U-III-1337/2009 (30/06/2010); U-III-54300/2009 (25/03/2010); U-III-1475/2008 (08/09/2010).

${ }^{37} \mathrm{U}-\mathrm{III}-1001 / 2010(7 / 07 / 2010)$.

${ }^{38}$ U-I-2665/2009; U-I-3118/2011 (30/01/2014).
}

CONSTITUTIONAL LAW REVIEW 


\subsection{Conflict of the Principles of Equality and Constitutional Design of the Voting Rights in the Republic of Croatia}

An example of a deviation from the principle of equality in the Croatian constitutional law system is the regulation of voting rights. Pursuant to the provisions contained in Article 45 of the Constitution, Croatian citizens aged 18 and over have universal and equal voting rights and can participate in the decision-making process on a state referendum. Active voting right shall be exercised in direct elections by secret ballot at polling stations in the country or at polling stations at the seats of the diplomatic and consular offices of the Republic of Croatia in a foreign country where the voter resides. Passive voting rights are additionally limited by incompatibility with the behavior of some public functions or the pursuit of certain professions ${ }^{39}$. At first glance, the constitutional arrangement of electoral rights is regulated here in a classical way, whereby every voter can express his or her opinion during the election and express his attachment to the community through the desire to participate in its democratic organization. Voting right is governed by the Constitution as a foundation of democracy based on active enjoyment of rights and fulfillment of duties as a process in which to participate and to engage in the pursuit of general good. On the other hand, policy makers and executors are people with political legitimacy gained in the last free elections.

The factual inequality of the electoral rights derives from Article 45 para. (2) of the Constitution, which establishes a fixed quota of representatives elected by nationals residing abroad, whereby this quota currently consists of three representatives, regardless of the number of potential voters. Namely, the prescribed fixed constant quota does not respect the proportionality between the number of voters with the right to vote in a special constituency and the actual number of votes that candidates in that unit have to obtain in order to obtain the status of a representative. The consequence of this arrangement is the fact of deviating from the electoral results of the principle of equal rights of voting rights in all the elections held in our country in the third millennium ${ }^{40}$. The inequality of the electoral right under the current normative decision derives from the fact of a mismatch in the number of the electorate in the legally established constituencies, whereby voters do not have the same electoral power to influence the formation of the state body ${ }^{41}$.

The specificity of the constitutional determination of the electorate is also reflected in Article 15 para. (3) of the Constitution, which stipulates that in addition to the general right to vote, members of national minorities may determine the right to elect their

\footnotetext{
${ }^{39}$ Article 9. The Electoral Act on the Croatian Parliament (“O.G." no. 116/99; 109/00; 53/03; 167/03; 44/06; 19/07; 20/09; 145/10; 24/11; 93/11; 19/15; 104/15).

${ }^{40}$ Article 2 of the Hungarian Constitution, Article 62 para. (2) of the Romanian Constitution.

${ }^{41}$ See M. Gjidara, In general about the right to vote and about the electoral right of emigrants, in Proceedings of the PFS, 52 (2015), 2 (116); pp. 279-309.
} 


\section{Dubravko LJUBIĆ}

representatives to the Croatian Parliament according to specially prescribed rules ${ }^{42}$. This is the privilege of members of national minorities, i.e. the right that does not belong to the majority population, which is manifested in the right to choose the participation in the electoral process according to the general rules or a special regime in which members of the national minority, if they so wish, can choose persons exclusively of identical ethnicity or persons of particular ethnicity. The aforementioned constitutional solution is indisputably contrary to the principle of the electoral right conferred by Article 45 of the Constitution. Article 15 para. (3) of the Constitution was the constitutional basis for the adoption of an organic Law on the Rights of National Minorities, which furthered the differentiation of voting rights among members of certain national minorities. Legislative regulations have allowed the Serbian national minority to have fixed three deputies in parliament, then Italian, Hungarian and Czech for one while other minorities are represented by one representative depending on whether their parent states were or were not part of the former SFRY43.

Here I take the opportunity to point out that minority rights are not fundamental human rights, nor are they suitable content for integral regulation of the basic norm. Rights of national minorities regulated by virtue of the legal norm do not include all members of the same national minority in the entire territory of the domicile state, since the exercise of these rights is usually linked to autochthonousness or numeracy in a given territory smaller than the one defined by the state boundaries. On an international level, additional rights are acknowledged for national minorities, like the right to use their language and script in private and official use, the right to education on the grounds of their cultural tradition and the establishment of educational

\footnotetext{
42 According to the census of 2011, the Republic of Croatia has 4.284 .889 inhabitants, out of which 328.738 are members of national minorities; Albanians 17.513 (0.41\%), Austrians 297 (0.01\%), Bosniaks 31.479 (0.73\%), Bulgarians 350 (0.01\%), Montenegrins 4.517 (0.11\%), Czechs 9.641 (0, 22\%), Hungarians 14.048 (0.33\%), Macedonians 4.138 (0.10\%), Germans 2.965 (0.07\%), Poles 672 (0.02\%), Roma 16,975 (0.40\%), Romanians 435 ( 0.01\%), Russians 1.279 (0.03\%), Rusins 1936 (0.05\%) Slovaks, 4.753 (0.11\%), Slovenians 10.517 (0.25\%), Serbs 186.633 (4.36\% 17807 (0.42\%), Turks 367 (0.01\%), Ukrainians 1.878 (0.04\%), Valachs 29 (0.00) and Jews 509 (0.01\%).

${ }^{43}$ At the last elections in Croatia, 211.267 voters were registered in the electoral list for the election of national minority representatives, and 37.957 voters voted. For the election of three representatives of the Serbian national minority, there were 19.561 votes out of the total of 138.539 registered voters in the voter list. A total of 5.213 voters voted for the election of the Hungarian national minority representatives from the total number of 9.981 voters enrolled in the voter list. A total of 2.338 voters voted for the election of the Italian national minority representatives from the total number of 11.440 voters enrolled in the voter list. For the election of representatives of the Czech and Slovak national minorities, 1.591 voters voted from the total of 6.763 voters enrolled in the voter list. For the election of representatives of the Austrian, Bulgarian, German, Polish, Romany, Romanian, Ruthenian, Russian, Turkish, Ukrainian, Vlach and Jewish minorities voted 3.847 voters out of 14.767 registered voters in the electoral list. For the election of representatives of the Albanian, Bosniak, Montenegrin, Macedonian and Slovenian national minorities, there were 5.470 voters from the total of 29.777 registered voters in the voter list. To enter the Sabor, Z. Milanović won 42.265 votes, A. Plenković 33.265 votes, and B.Esih 10.471 votes, while from minority lists, M. Pupovac entered the Parliament with 16.166 votes; R. Jankovics with 2.731 votes; F. Radin with 1.676 votes; V. Bilek with 1.329 votes; V. Kajtazi with 2.010 votes, and E.L. Prljaskaj with 1.354 votes.
}

CONSTITUTIONAL LAW REVIEW 


\section{Principle of equality as the basis of the constitutional order}

institutions, the right to access and media organization, and the right to peaceful and non-existent harmful cooperation with the mother state of its nation. These rights are conditional and depend on the existence of a link of citizenship, loyalty to the domicile state, indigenousness or number in a particular territory, demand for the corresponding rights, and the existence of the need and the ability to exercise these rights ${ }^{44}$. Therefore, any privilege within the institute of voting rights, even though it was prescribed by the constitution and the law, which has no basis in the election results obtained in the elections conducted in accordance with the principle of equal electoral power of voters, would not be in accordance with the principle of equality, which, as set out in Article 3 of the Constitution, is the highest value of our constitutional order and the foundation for the interpretation of the Constitution ${ }^{45}$.

Since 1991, the legislator has been mandating members of national minorities to legally guarantee and secure a certain number of seats in the Croatian Parliament in the elections conducted on the basis of special legal rules for members of national minorities in a special constituency. Members of national minorities could freely choose whether to vote for their MPs on the basis of general and equal electoral rights in general constituencies or as members of a national minority for members of national minorities in a special constituency. Regardless of the number of votes by which the national minority candidate was elected to a seat in the Croatian Parliament, they in their mandate, their parliamentary powers, rights, duties and responsibilities, were fully equal with the representatives who had been elected to Croatian Parliament elected within the general election system. Thus, a vote of a member of a national minority at the parliamentary elections in Croatia simultaneously carried the potential of the general vote and the potential of a special vote. As the Constitution accepts the civil concept of the country in which all its citizens are a nation, i.e. a community of free and equal citizens who exercise the power by electing their representatives in a representative body on the basis of universal and equal electoral rights, then it is constitutionally suspect to legally guarantee and determine the number of seats of any minority within the electoral system in advance. Any separation of any social group from the total corpus of citizens by any criterion, and thus the criterion of nationality, and the creation of a solution in which such a group is particularly represented in political life is constitutionally unacceptable. Potential recognition of a special voting right to members of national minorities must have its rational basis and reasonable justification based on factual substratum. It must be legitimate from the aspect of

\footnotetext{
${ }_{44}$ Framework Convention for the Protection of National Minorities of the Council of Europe; Strasbourg (10/11/1995); entered into force on 01/02/1998; a series of European international treaties no. 157; "0.G." no. 14/97, dated 09/10/1997; and the Confirmation Act of 29/09/1997.

45 See: M. Jelušić, Constitutional Changes and Equality of Voting Rights, in Informator, 57 (2009), Small Pages (5821); pp. 4-6; R. Podolnjak, Constitutional Court, Electoral Elections for Election of Members in the Croatian Parliament and Principle of Equality of Voting Rights, in Informator, 59 (2011), 5934; pp. 5-6; M. Palić, Unequal Voting Rights in the Republic of Croatia, in Legal Gazette, PFO, 27 (2011), no. 3-4, pp. 331-224.
} 


\section{Dubravko LJUBIĆ}

proportionality, which means that securing a minority's special right to vote could only be justified if there were no milder means to achieve the goal to be achieved, that is to say, such means that would not affect the equality of the general voting right.

Pursuant to the Constitution, in the Republic of Croatia, people are empowered by the election of their representatives and immediate decision-making. The elected representatives of the people have no binding mandate, but a representative mandate as the fundamental form of exercising national sovereignty. The system of national rule is constitutionally expressed through a representative system deriving from the theory of indivisible national sovereignty. Representative term means such a relationship between voters and their representatives, according to which the representatives are independent in their actions from the attitudes of voters who have chosen them, so therefore voters can not revoke them. The elected representative is the holder of the collective mandate he has obtained through the election. He represents the entire people, and not just the electors who chose him or the electoral constituency in which he was elected. The Constitution as a whole contains comprehensive principles that must be interpreted in all its individual provisions. Therefore, no constitutional provision can be derived from its context and interpreted autonomously. Each individual constitutional provision must always be interpreted in accordance with the highest values of the constitutional order that are the basis for the interpretation of the Constitution itself, including equality and national equality. Equality of electoral law means that a lawmaker through an appropriate electoral system needs to provide all citizens with the right to cast one vote or more votes, depending on the will of the legislator and the accepted electoral system, but this must always be equal number of votes for all.

\section{Conclusion}

Each society represents a set of individually different persons residing in a particular territory and subject to legal order. In democratic societies based on national sovereignty, the legal arrangement of social relations must be regulated in a way that guarantees the principle equality in the distribution of social goods or burdens to all members of society. Civil societies that do not immanently differentiate themselves by birth, in order to have the attribute of righteousness, must ensure universal equality as the basis of their participation in social relationships. In constitutional states, this social function exercises the constitutional principle of equality. The principle of constitutional equality creates a defense from creating socially undesirable differences between its members based on circumstances that are not socially relevant. It also protects all individuals in exercising their constitutional rights and freedoms in such a way that it forbids the legislator and any other authority of normative activity to regulate social 
relations with a norm that differentiates its addressees in a constitutionally unacceptable manner. The principle of equality primarily for all members of the company ensures that normative activities are treated equally. This principle in its general substrate protects the discrimination of any individual or social group on any socially important basis. It does not allow the legislator to elaborate the rights and freedoms of the individual under the minimum content guaranteed to each member of the society, but also any actions that place addressees in a discriminating position deprived of any social and rational basis when exercising their constitutional rights and freedoms. For this reason, the constitutional principle of equality is practically enshrined in the enjoyment of every constitutional right and freedom, i.e. in the content of any constitutional guarantee whose substrate remains beyond the reach or influence of the state. At the same time, the constitutional principle of equality acts as a requirement put forward by the legislator for equal treatment of addressees in normative activity. Here the legislator is obliged in principle to treat the same factual situation in the same way, and similar in a similar way. In doing so, the legislator is empowered to place certain social groups in a privileged position, but only according to the pre-established constitution contained in the criteria and in the way that others who are not covered by the privilege on their side do not establish a burden that would be disproportionate to the social purpose and goal which was to be achieved by certain normative activity. At the same time, the establishment of a privileged position must be carried out in a transparent manner and based on a rational basis that previously must be established as socially relevant. While treating as equal guarantees to everyone treatment deprived of any discrimination, equality in treatment is guaranteed by normative arrangements in which a realistically implemented differentiation in the non-privileged does not establish a socially unacceptable burden. Any differentiation of addressees in normative activity must have its legitimate purpose and social goal. Socially relevant circumstances for differentiation must at their origin have the achievement of general social benefit or the achievement of long-term socially acceptable benefits, both of the directly privileged ones and those who, according to a particular legal arrangement, are not. This content of the constitutional principle of equality is also the foundation of freedom and social justice in every democratic society. 